\title{
EVAPORITE GEO-HAZARD IN THE SAURIS AREA (FRIULI VENEZIA GIULIA REGION - NORTHEAST ITALY)
}

\section{Chiara Calligaris}

Dipartimento di Matematica e Geoscienze, Università degli Studi di Trieste, Via Weiss, 2, Trieste, 34128, Italy, calligar@units.it

\section{Stefano Devoto}

Dipartimento di Matematica e Geoscienze, Università degli Studi di Trieste, Via Weiss, 2, Trieste, 34128, Italy, sdevoto@units.it

\section{Luca Zini}

Dipartimento di Matematica e Geoscienze, Università degli Studi di Trieste, Via Weiss, 2, Trieste, 34128, Italy, zini@units.it

\section{Franco Cucchi}

Dipartimento di Matematica e Geoscienze, Università degli Studi di Trieste, Via Weiss, 2, Trieste, 34128, Italy, cucchi@units.it

\begin{abstract}
Evaporite sinkholes represent a severe threat to many European countries, including Italy. Among the Italian regions, of the area most affected is the northern sector of Friuli Venezia Giulia Region (NE Italy). Here chalks had two main depositional periods first in the Late Permian and then during the Late Carnian (Late Triassic). Evaporites outcrop mainly in the Alpine valleys or are partially mantled by Quaternary deposits, as occur along the Tagliamento River Valley. Furthermore, evaporites make up some portions of mountains and Alpine slopes, generating hundreds of karst depressions.
\end{abstract}

This paper presents the preliminary results of the research activities carried out in Sauris Municipality where sinkhole phenomena related to the presence of gypsum are very common.

Field investigations were devoted to recognition, mapping and classification of evaporite sinkholes. To recognize sinkhole phenomena, the preliminary steps included the analysis of historical documents collected in archives, the analysis of aerial photos and Airborne Laser Scanning (ALS) surveys. The integration of the abovecited activities allowed a preliminary identification of the phenomena, which were later validated by detailed field surveys.

All the collected data populate a geo-database implemented for a project funded by the Geological
Survey of Friuli Venezia Giulia Region. The objective of this project is to inventory and classify the sinkholes associated to evaporite rocks.

\section{Introduction}

Subsidence phenomena associated to the presence of evaporite rocks are common in Europe. Evaporite sinkholes affect the central and northern part of England (Cooper, 2008), Lithuania (Taminskas and Marcinkevicius, 2002), NE Spain (Gutiérrez, 1996; Gutiérrez and Cooper, 2002; Guerrero et al., 2004; Gutiérrez et al., 2008) and Albania (Parise et al., 2004; Parise et al., 2008).

As reported by Nisio (2008) and by Caramanna et al. (2008), sinkholes occur also in Italy where are distributed along the whole peninsula, especially in some regions, such as Sicily, Lazio, Campania, Alto Adige, Puglia, and Friuli Venezia Giulia.

The Friuli Venezia Giulia Region is located in the NE part of Italy and covers an area of 7,858 $\mathrm{km}^{2}$. Here are present 221 municipalities of which approximately 40 coexist with geo-hazard problems associated to the existence of outcropping or mantled karstifiable rocks. Limestones and dolostones represent approximately $24 \%$ of the whole regional territory, whereas evaporite rocks do not exceed 1\% (Figure 1). In all those areas, where evaporites and limestones outcrop or are mantled by quaternary deposits or other rock types, sinkholes 


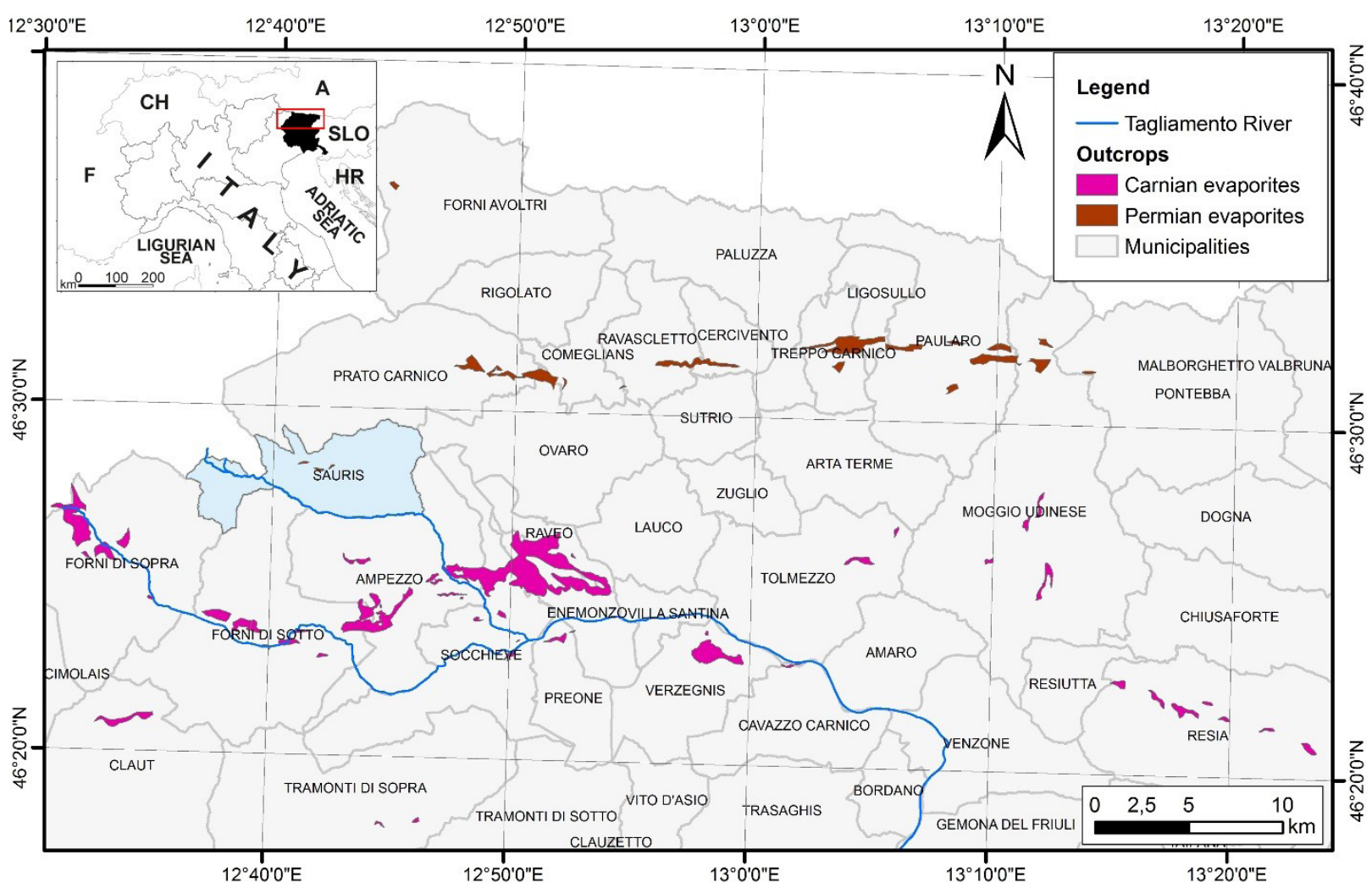

Figure 1. Location of the study area (pale blue), which is situated in the NE Italy. Pink and brown areas indicate the main evaporite outcrops.

are widespread. Despite the low percentage of evaporite rocks, sinkholes associated with these lithologies represent a major hazard for human facilities. As reported by Zini et al. (in press), the northern portion of Tagliamento River Valley is affected by several sinkhole phenomena, which caused and are still causing severe damages to the existing infrastructures. This area has been historically hit by subsidence phenomena since 1960s, as reported by Gortani (1965).

The sinkholes situated in the northern part Friuli Venezia Giulia Region are caused by evaporites originated as the result of two main depositional episodes occurred respectively at the end of the Permian (Bellerophon Formation) and in the Carnian (Raibl Formation) (Venturini et al., 2006). In this context, evaporites, in the Friuli Venezia Giulia Region played an important role during the Alpine tectonic compressions, during which they may be treated as tectonic lubricant. Evaporites mainly outcrop in the valley floors, but can be identified also in the mountains, and this is the case of Sauris Municipality. Here quartz sandstones and micasiltstones belonging to the Werfen Formation (Triassic) are widely present. These rocks, capping evaporitic ones, belonging to the Bellerophon Formation, are jointed and characterized by a secondary permeability. Over time, water infiltration and weathering led to the solution of the Permian evaporites and to the progressive failure of the overlying terrigenous rocks, less soluble but more plastic. The result is the genesis and evolution of depressed landforms classifiable as sinkholes giving to the Alpine environment peculiar morphologies.

This paper illustrates the results of the research activities performed in the Sauris Municipality, which is the area of the NE Italy most affected by sinkhole phenomena related to the presence of evaporite rocks and clearly visible on the topographical surface.

Evaporite sinkholes were recognized and classified by means of traditional activities such as desk analysis and field surveys.

\section{Study Area}

The Sauris territory has an area of about $42 \mathrm{~km}^{2}$, and a mean elevation of $1,212 \mathrm{~m}$ with an inhabitant density of 10 persons $/ \mathrm{km}^{2}$. Even if the average elevation is not so high, in the northern side of Sauris, some peaks as 
Bivera Mountain reach an altitude of 2,474 m. In this municipality, evaporite rocks are not so common at the surface because they are overlyed by Werfen Formation or mantled by Quaternary deposits. The presence of sinkhole phenomena is historically known in this area (Calligaris et al., 2009). Tens of sinkholes were recognized on the valley bottoms, over the top of the ridges and in the middle of the slopes. Their presence partially compromises urban expansion and consequently affects land use planning. In the villages and settlements, this situation represents a severe geo-hazard for human facilities and inhabitants (Figure 2).

\section{Geological Overview of the Area}

From a geological viewpoint, Bellerophon Formation and Werfen Formation are the most important. The Bellerophon Formation is a regionally extensive unit, outcropping from Slovenia to Veneto Region. The intensity of the alpine tectonic deformations strongly affected its stratigraphic continuity. In fact, it is difficult to find a comprehensive section and it frequently appears cataclastic (Venturini et al., 2006).

It is difficult to define the original thickness of this unit due to the presence of several thrusts and high rates of gypsum dissolution (Buggisch and Noè, 1986). The unit is mainly outcropping in a wide belt coincident with the valley bottoms. regional structural trend. This fault is $40 \mathrm{~km}$ long from West to the East of the Region reaching the Tagliamento River where is present its further eastern portion. The above-cited fault permits Permian units to overlap the Triassic rocks. The presence of gypsum at the base of the northern overthrusted units facilitated the process. The Sauris Fault is also crossed by secondary faults.

The Bellerophon Formation incorporates two different members: at the base gypsum alternates with black dolostone (thickness of about $60 \mathrm{~m}$ ) whereas the upper member consist of dolostones and black limestones (200 $\mathrm{m})$. The plastic behavior causes strong deformations of the evaporite member that for this reason seldom outcrops. Conversely, the upper Member widely outcrops (Carulli, 2006; Venturini et al., 2006).

In the northern part of the study area, the Bellerophon Formation is capped by Werfen Formation (Early Triassic). Werfen Formation incorporates six different members. The lower member consists of an oolitic limestone with an average thickness less than $7 \mathrm{~m}$. Middle members are made up by limestones and marls, dolomitic limestones, marls and pelites, alternating calcareous sand and mud with a thickness of approximately $200 \mathrm{~m}$. The Formation ends up with a member of fine-grained violet sandstones and pelites, reaching a thickness of about 200 m (Carulli, 2006; Venturini et al., 2006).

In the study area, the main discontinuity is the E-W oriented Sauris Fault (Figure 3), which follows the

Moraine deposits partially mantle the valley bottoms and the flat parts of the highlands.

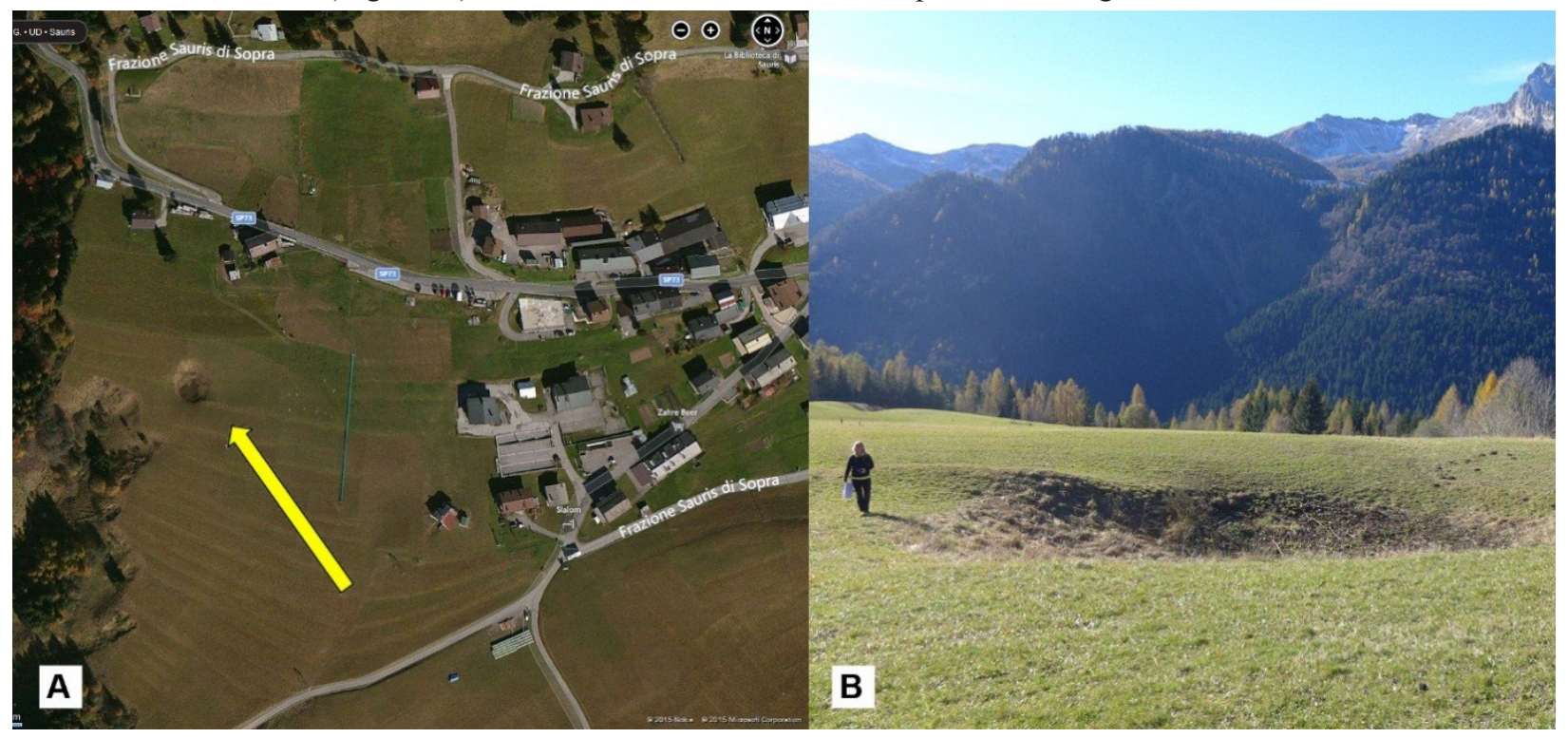

Figure 2. Aerial (A) and oblique (B) views of a sinkhole located near Sauris Village. 

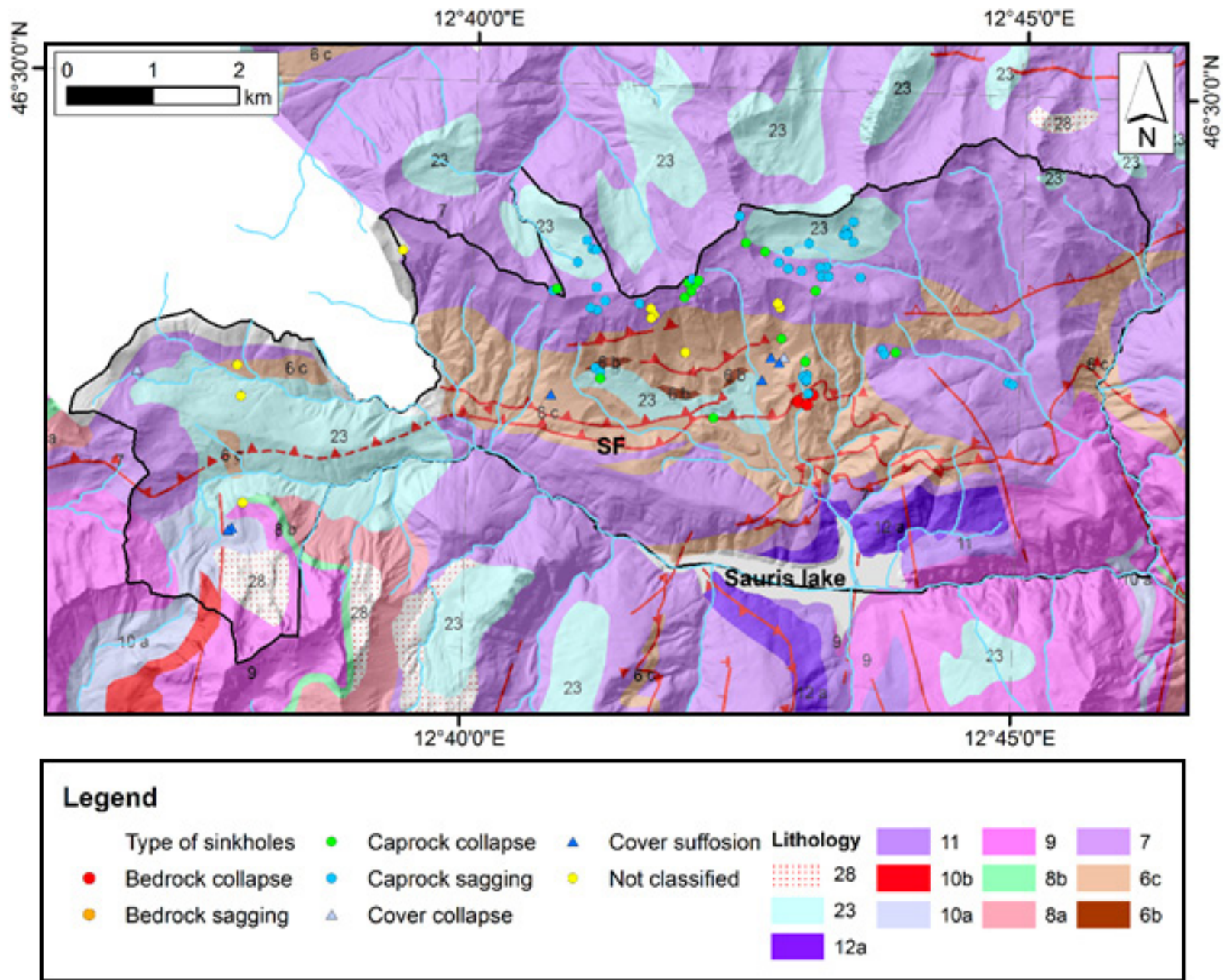

Figure 3. Spatial distribution of sinkholes affecting Sauris Municipality. The different colors indicate the types of sinkholes. 28= Quaternary deposits; 23= Moraine deposits - Late Pleistocene; 12a= Carbonates alternated with marls - Late Trias; 11 = Carbonates alternated with marls - Late Trias; $10 b=$ Vulcanites - Trias Middle; 10a= Sandstones and shales (flysch) - Middle Late Trias; 9= Massive carbonates - Middle Late Trias; $8 a=$ Massive carbonates - Middle Trias; $8 b=$ Sandstones and shales (flysch) - Middle Trias; 7= Sandstones and shales (flysch) Werfen Fm. - Early Trias; 6c= Carbonates alternated with marls (Bellerophon Fm.) - Late Permian; 6b= Evaporites (Bellerophon Fm.) - Late Permian. In red the main thrusts (after Carulli, 2006); SF= Sauris fault.

\section{Methods and Results}

To recognize sinkhole phenomena, the preliminary steps have included the analysis of historical documents collected in archives and the study of scientific papers and technical reports. These investigations have permitted us to define the geological setting of the Sauris area and to outline the possible locations of sinkholes associated with the carbonate and evaporite rocks.

These preliminary stages were integrated with the interpretation of aerial photos and ALS surveys acquired recently by Regional Civil Protection.
The above-mentioned activities allowed us to identify the surface morphologies and later to recognize the sinkholes. All the desk data were validated by field surveys (Figure 2). Particular attention was devoted to the selection of the sinkhole classification. In the present paper, we used the methodology developed by Gutiérrez et al. (2008), which was the most suitable for the encountered evaporitic phenomena.

We recognized and classified 73 sinkholes (Figure 3 ); the caprock sagging sinkholes are dominant (49) and are common in the northern part of the study area 
(Figure 4). Caprock sagging sinkholes involve the Werfen Formation, which overlies the Bellerophon Formation. For this type of sinkhole the circular or subcircular shape is prevalent. Figure 5 shows two adjacent sinkholes. The left sinkhole (A) is a caprock collapse sinkhole characterized by steep slopes, whereas the right (B) caprock sagging sinkhole is in an early stage of evolution.

Although bedrock collapse sinkholes are extremely rare, two spectacular features of this type were observed 500 meters East of Sauris di Sotto Village. These phenomena involve Bellerophon Formation rocks and are limited by steep slopes (Figure 6). The diameters exceed $100 \mathrm{~m}$ and one of it is characterized by the presence of a pond at the bottom. These karst depressions can reach depths of tens of meters. The sinkhole slopes are affected by abundant falls of trees and debris. These bedrock collapse sinkholes

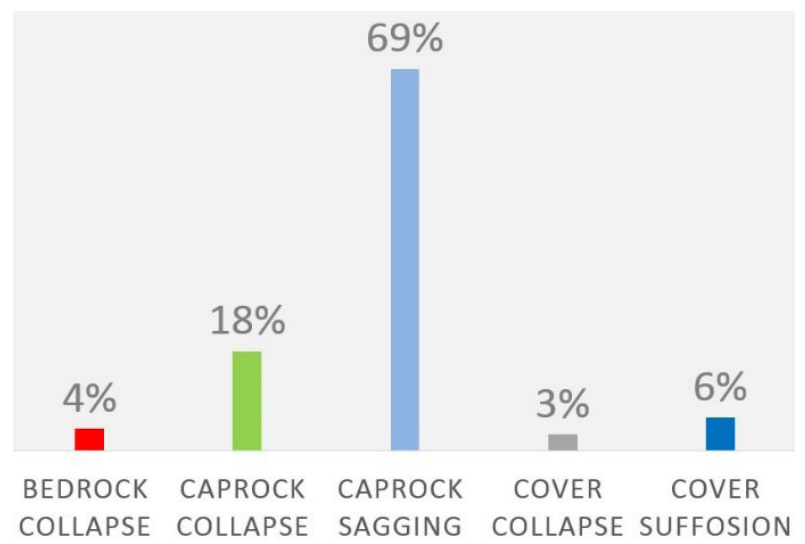

Figure 4. The bars indicate the different type of sinkholes. Caprock sagging sinkholes are dominant.

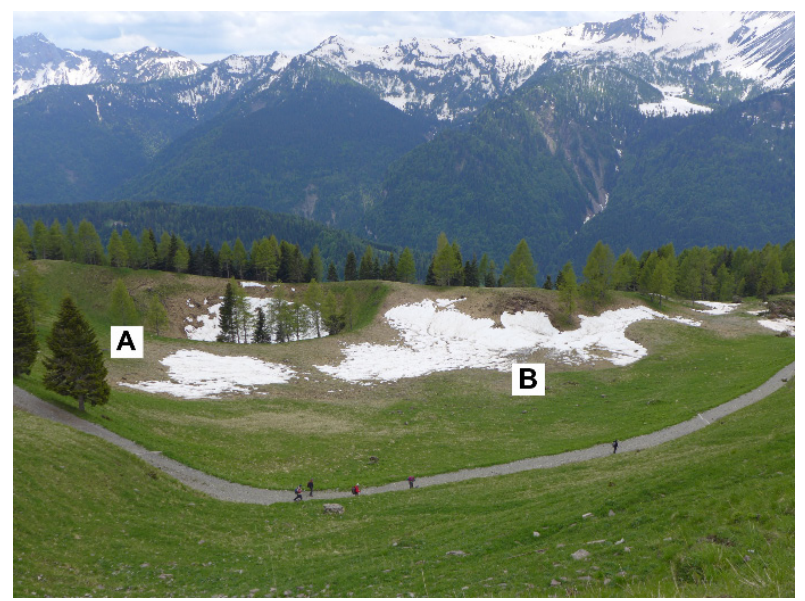

Figure 5. Oblique view of two sinkholes affecting Werfen Formation. are associated with heavy rainfall, which often exceeds 2,000 mm per year in northern Friuli, and mainly by the presence of a torrent, which accelerates the dissolution processes and the gypsum erosion.

The cover suffosion sinkholes (5) and cover collapse sinkholes (2) are mainly located near Sauris di Sotto and involve the Quaternary glacial deposits.

\section{Conclusions}

The results of the integrated analysis has produced an inventory of sinkholes associated with the evaporite rocks in the Sauris Municipality. Here, different types of karst phenomena occurred and involve mainly the Werfen Formation, which overlies the evaporites of the Bellerophon Formation.

The sinkholes located in the surroundings of the top of mountains situated in the northern part of Sauris Municipality, affect a $200 \mathrm{~m}$ thick of poorly-karstifiable formation.

This is due to the different mechanical properties of the Werfen and Bellerophon Formations. Conversely,

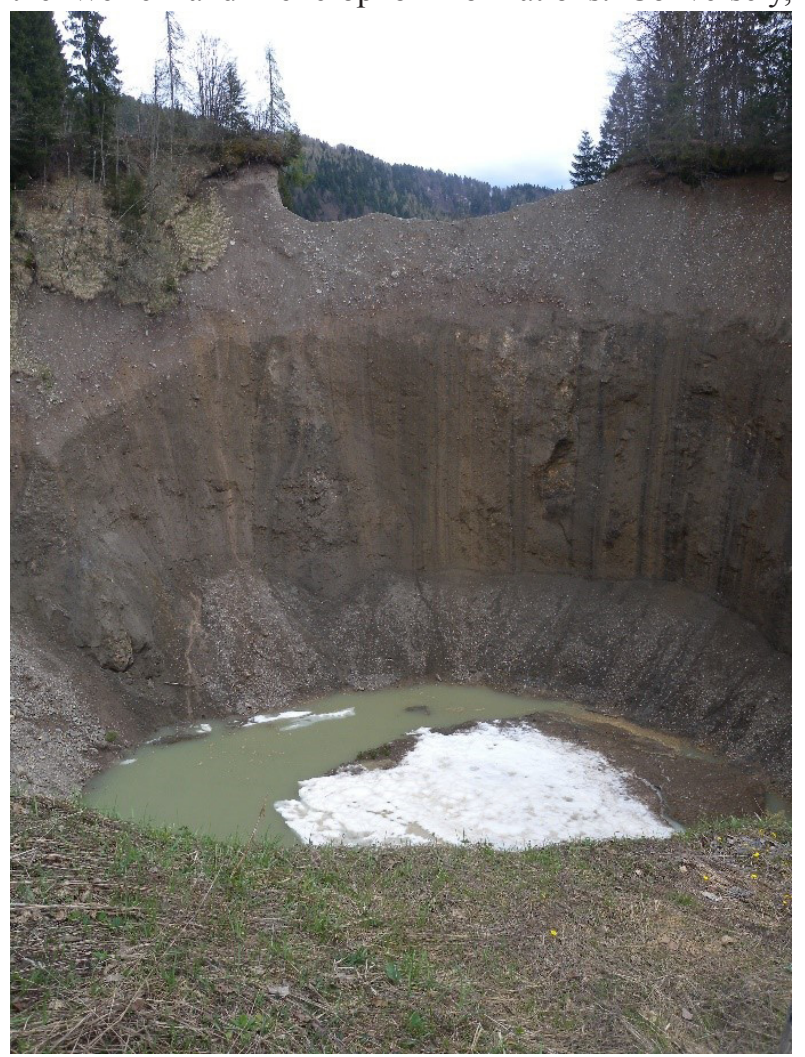

Figure 6. View of a $30 \mathrm{~m}$ deep bedrock collapse sinkhole. 
bedrock collapse sinkholes are scarce but are characterized by huge sizes and depths. The maximum depth exceeds $35 \mathrm{~m}$.

The spatial distribution of sinkholes does not coincide with any particular structural alignment even if the investigated area is crossed by several regional faults, which are oriented approximately E-W.

Thanks to the financial support of Regional Geological Survey, the research activities here presented are not limited to Sauris area but include all the municipalities of Friuli Venezia Giulia Region. At present, we have inventoried approximately 200 sinkholes, spreaded among Forni di Sopra and Tolmezzo villages (Figure 1). Type, size, depth, and other major morphometric characteristics of each phenomena populate a Geodatabase. The latter is crucial to assist local authorities to recognize areas affected by geo-hazard associated to evaporite rocks and can be used for landplanning purposes.

\section{References}

Buggisch W, Noè S. 1986. Upper Permian and PermianTriassic boundary of the Carnia (Bellerophon Formation, Tesero Horizon, northern Italy). Memorie Società Geologica Italiana 34: 91-106.

Calligaris C, Zini L, Cucchi F, Stefanelli N. 2009. Gypsum's role in the Friuli Venezia Giulia sinkholes. Proceedings of the $2^{\circ}$ Seminario "I sinkholes: gli sprofondamenti catastrofici nell'ambiente naturale ed in quello antropizzato", ISPRA. Roma, 213-221.

Caramanna G, Ciotoli G, Nisio S. 2008. A review of natural sinkhole phenomena in Italian plain areas. Natural Hazards 45: 145-172.

Carulli GB. 2006. Carta geologica del Friuli Venezia Giulia alla scala 1:150.000 e Note Illustrative. SELCA (Eds.), Firenze.

Cooper AH. 2008. The GIS approach to evaporitekarst geohazards in Great Britain. Environmental Geology 53: 981-992.

Gortani M. 1965. Le doline alluvionali. Natura e montagna 3: 120-128.

Guerrero J, Gutiérrez F, Lucha P. 2004. Paleosubsidence and active subsidence due to evaporite dissolution in Zaragoza area (Huerva River valley, NE Spain): processes, spatial distribution and protection measures for transport routes. Engineering Geology 72: 309-329.
Gutiérrez F. 1996. Gypsum karstification induced subsidence: Effects on alluvial systems and derived geohazards (Calatayud graben, Iberian Range, Spain). Geomorphology 16: 277-293.

Gutiérrez F, Cooper AH. 2002. Evaporite dissolution subsidence in the historical city of Calatayud, Spain: damage appraisal and prevention. Natural Hazards 25: 259-288.

Gutiérrez F, Guerrero J, Lucha P. 2008. A genetic classification of sinkholes illustrated from evaporite paleokarst exposures in Spain. Environmental Geology 53: 993-1006.

Nisio S. 2008. I sinkholes nelle altre regioni. Memorie Descrittive della Carta Geologica d'Italia 85: 419-426.

Parise M, Qiriazi P, Sala S. 2004. Natural and anthropogenic hazards in karst areas of Albania. Natural Hazards and Earth System Sciences 4: 569-581.

Parise M, Qiriazi P, Sala S. 2008. Evaporite karst of Albania: main feature and cases of environmental degradation. Environmental Geology 53: 967-974.

Taminskas J, Marcinkevicius V. 2002. Karst geoindicators of environmental change: The case of Lithuania. Environmental Geology. 42: 757-766.

Venturini C, Spalletta C, Vai GB, Pondrelli M, Fontana C, Delzotto S. 2006. Note illustrative della Carta Geologica d'Italia alla scala 1:50.000, Foglio 31 Ampezzo. Eds. Università di Bologna, p. 232.

Zini L, Calligaris C, Devoto S, Zavagno E, Forte E, Boccali C, Petronio L, Cucchi F. In press. Fenomeni di sprofondamento nella piana di Enemonzo (UD). In proceedings of $3^{\circ}$ Workshop internazionale: Voragini in Italia, I sinkholes e le cavità sotterranee: ricerca storica metodi di studio ed intervento. 8 May 2014 Roma. 